\title{
Spatial Analysis of the Sustainability of Small Communities: A Case Study on the Island of Ilovik, Croatia
}

\author{
Elena van Roggen, Mila Zlatić
}

\begin{abstract}
This paper outlines the primary research conducted on the small island of Ilovik, Croatia and the following spatial statistical analysis performed with a central goal of examining current sustainability of the village and providing future planning recommendations. For two weeks in mid-June of 2011, residents were interviewed about their current socioeconomic status and perceptions of tourism, the natural environment, and government. Their responses were assigned numeric values with dummy variables excluding the least common response, and were entered as attributes of building footprint polygons digitized in a GIS to allow for spatial statistical analysis. Tests included Local and Global Getis Ord G, Ordinary Least Squares, and Geographically Weighted Regression. Clear hot and cold spots were found, showing where additional water sources are needed or where water quality should be addressed and that a coastal vs. inland divide exists. Weak correlations existed between income and all other attributes, but from the results one could suggest a focus on increasing tourism and decreasing the supply of houses for sale.
\end{abstract}

Key words: spatial analysis of sustainability, small communities, small islands, Ilovik

\section{Prostorna analiza održivosti razvoja malih naselja: primjer naselja na otoku Iloviku u Hrvatskoj}

U radu se iznose preliminarni rezultati znanstvenog istraživanja na otoku Iloviku u Hrvatskoj. Primarni cilj prostorne statističke analize bio je ispitati postojeću održivost razvoja naselja na otoku i dati smjernice za daljnje planiranje razvoja. Tijekom dva tjedna u srpnju 2011. provedeni su intervjui sa stanovnicima otoka u vezi s njihovim socioekonomskim statusom te pogledom na turizam, okoliš i vlast. Njihovim odgovorima dodijeljene su numeričke vrijednosti s binarnim varijablama (0 i 1) koje su isključile odgovore s najmanje sličnosti s ostalima. Vrijednosti su unesene kao atributi koji su pridruženi objektima koji predstavljaju građevine digitalizirane u GIS-u kako bi se omogućila prostorna analiza. Test uključuje lokalni i globalni Getis Ord G, Ordinary Least Squares i regresiju prema geografskom položaju. Utvrđena su područja s koncentracijom visokih i niskih vrijednosti („vruće” i „hladne” točke) koja upućuju na dijelove gdje je potrebno povećanje količine dostupne vode i poboljšanje kvalitete vode te gdje postoji razlika između kopna i obale. Utvrđena je niska korelacija visine prihoda i ostalih varijabli, ali rezultati pokazuju da su naglašeni rast turizma i smanjenje broja praznih objekata.

Ključne riječi: prostorna analiza održivosti, mala naselja, mali otoci, Ilovik 


\section{INTRODUCTION}

When a community is faced with changes in economy, society, or environment, it is essential to evaluate current sustainability and identify areas for improvement to accommodate the anticipated change. About to become a member of the European Union (EU), Croatia foresees increases in international tourism and swift changes in property ownership from introduction to the international market (Lončar and Maradin, 2009; Krstinić Nižić et al., 2010). These changes could improve a dwindling economy and an aging and decreasing population. A boost in income from tourism and the resulting increase in employment opportunities could slow down emigration or even bring people back, essentially fulfilling two of the three requirements of sustainability - economy and society (Hawkes, 2003; Ciegis, Ramanauskiene and Martinkus, 2009) - giving Croatia a better outlook for the future.

Some smaller communities in Croatia require improved infrastructure and planning in order to accommodate the influx of income and population (Krstinić Nižić et al., 2010). Croatian islands are specifically in need of re-evaluation as depopulation has a larger effect on smaller, isolated communities (Cross, 1996; Deschenes and Chertow, 2004). This study examines the current sustainability of Ilovik, a small Croatian island village, and will give recommendations as to how to improve on the village's infrastructure and layout.

While this study is focused on urban planning, monocentric or decentralized patterns traditionally used in urban planning (Yeh and Li, 2001) may not be the best models for island communities due to their small sizes, populations, and general rural characteristics. The village considered in this study is one of the smallest island communities in the country, and lacks even vehicular transportation and water and sewage systems. Instead of the traditional monocentric or decentralized patterns traditionally used in urban planning, the "triple bottom line approach which incorporates social economic, and environmental considerations" (Pettit, 2005) would be more appropriate given the unique traits of the village of interest. The views of the townspeople and their current socio-economic statuses, along with the specific needs of the island itself, must be taken into consideration.

Geographic information systems are key tools in the evaluation of a community and determination of necessary changes in infrastructure. They allowed for in-depth examination of the current socio-economic situation on Ilovik and provided a platform for qualitative spatial analysis to aid in the creation of planning recommendations. Spatial statistics were utilized in this study to identify relationships between traits of residents and their associated location on the island. By incorporating the resident survey results, geographic information systems filled in the socio-economic gap in traditional planning methods

\section{SITE CHARACTERIZATION}

Ilovik is an island in the Northern Adriatic of only about two square miles and eighty permanent residents, and about 180 houses (Fig. 1). Population in the summer months increases heavily, as dual residents, vacation home owners, and tourists return to the island. The vegetation is primarily Mediterranean, with small shrubs and trees dominating the landscape. Olive farming and vine production were once a large source of income 


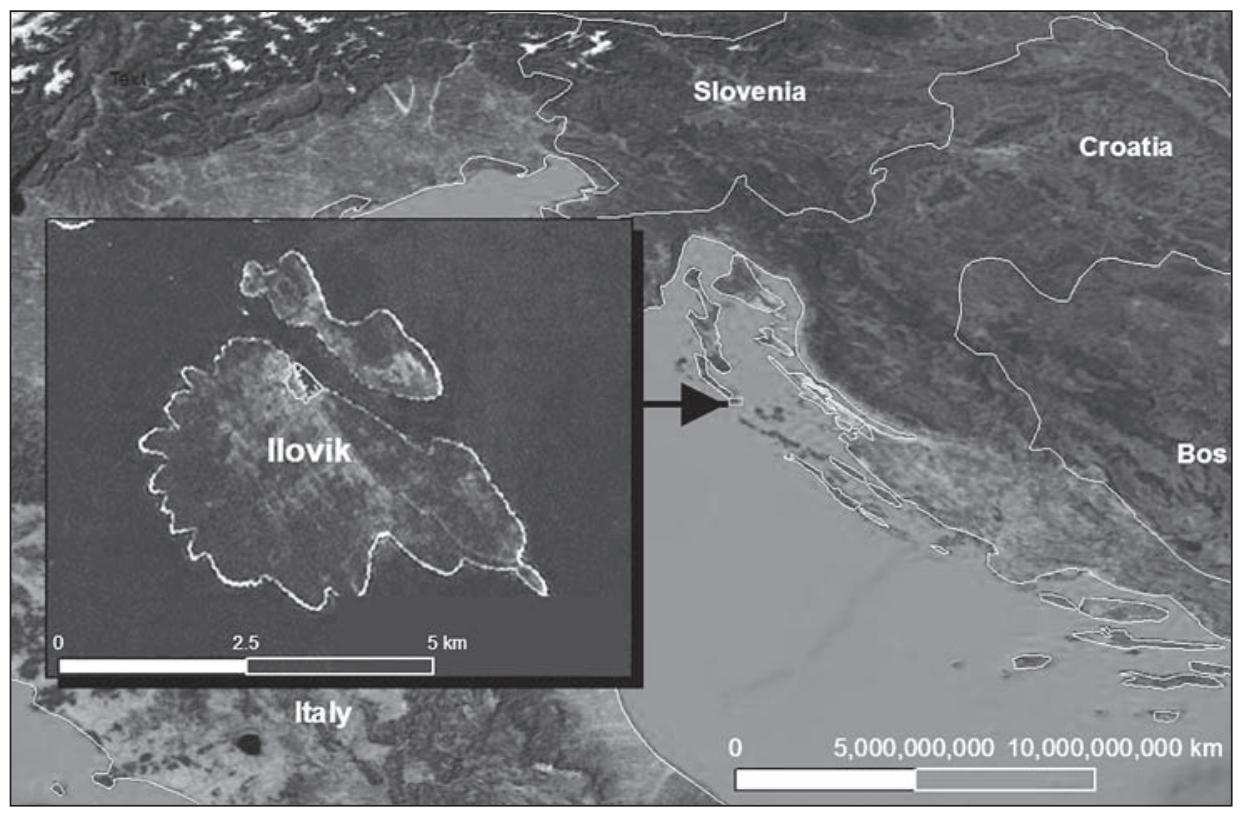

Fig. 1 Geographical position of the island and the village of Ilovik

Sl. 1. Geografski smještaj otoka i naselja Ilovika

for residents in the past. (Stražičić, 1997). Now, the majority of the land is overgrown or used for grazing sheep, though lavender farming has slowly started to pick up pace with a couple vacation home owners. Karst topography is prominent across the island, as many of its numerous bays are lined with limestone outcrops.

The village encompasses an area of less than a quarter square mile, with the main street running parallel to the shoreline. Along this street, one pier exists long enough to accommodate larger tourist ships and is therefore considered the main port. Construction of its extension started in September 2011. In most areas, the village reaches the extent of the approved zone of construction, with a small portion outside the zone to the north, and some of the zone in the southwest unutilized (Master Plan, 2011). The streets - or "paved footpaths", as only one motorized vehicle exists on the island - are not named, numbered, or organized in any grid pattern aside from branching off the main street. While a government post office is present on the island, addresses are unimportant and confusing, as numbers were added after houses were built, and then were renumbered once more afterwards. Some houses were built without permits, and are referred to in the study as "BB” along with an identifying number. There exist a handful of private businesses, nearly all of which rely on tourism and are located along the shoreline.

The island was once a thriving community of farmers and businessmen; but is now a diminishing village of retirees and empty fields (Lajić, 2005). With no one willing or able to work the land and few employment opportunities of any sort, the island's sustainability is in question. 


\section{METHODOLOGY}

In mid-June of 2011, nearly all the residents present on the island during the study period were extensively interviewed, including $95 \%$ of the households of permanent residents and many temporary resident households. The residential survey included questions covering the demographics and economic status of the interviewees, and their perceptions of tourism, the natural environment, and government involvement in the development of the island. The survey, created under the topic of sustainable development, gathered general information about the respondent's household, properties, land ownership, labour, and their perception of issues such as drinking water, sewage, pollution, tourism effects and trends, agricultural sustainability, development laws, and local and national government, among other things. A modified version was then created to serve as a private business interview, providing non-residential socio-economic data to complete the village's dataset.

A complete address map of each building in the village was hand drawn from aerial imagery and digitized in a GIS, to which interviewee attributes were attached based on addresses and ground truthing where necessary. Of all the buildings on the island, 59 heads of households were interviewed, 57 heads of households were absent or declined the interview, 19 were vacant, 15 were unaccounted for, and 17 were not residential (i.e. rental apartments) (Fig. 1).

The spatial analysis portion of the study has two main goals: determining the state of the village in terms of sustainability, and providing suggestions for future improvement. To evaluate the village's current sustainability in a spatial manner, relationships between interview variables must also be examined in terms of their relative locations. Variables must be tested for spatial autocorrelation to identify patterns, "hot spots" and "cold spots", and trends to help determine ideal changes in infrastructure and development. Regression analysis is a key tool for identifying cause-and-effect relationships not only between variables, but also between variables and the location relative to certain features. A better understanding of these relationships may provide insight into what the village needs most in anticipation of economic and societal changes.

Due to the nature of the study's dependence upon co-operation, it was difficult to ensure data quality and wholeness. Often interviewees would not respond to a question, refuse to respond, digress in response, or give unclear responses. For the purposes of this analysis, any unclear or incomplete answer was considered as if none had been given; though an analysis of different response types would likely prove interesting as well. During the first few days of data collection, the interview was modified slightly to improve clarity and organization. Therefore, earlier interviews may not have all the questions later interviews do, but this slight change has not influenced the results of this analysis.

First, spatial autocorrelation of variables was examined to find "hot spots" in traits such as age and income of the heads of household, as well as vacant buildings and private businesses in the village. Preliminary analysis was performed in a GIS using the Global Getis-Ord General G test to see if any spatial pattern existed, and to what degree. Getis Ord tests examine not only if a spatial pattern exists, but also whether clusters are of high or low values. All tests examined the inverse Euclidian distance squared between points due to the general small scale of the village and its lack of vehicular streets. The questions 
whose results yielded a clustered spatial pattern according to Global Getis-Ord General G tests were then tested using Local Getis-Ord Gi* using the same parameters, a test which locates and displays the hot and cold spots. The results are shown in the Appendix.

Second, regression analysis was performed to examine any possible relationships between a household's monthly income and their socio-economic status and perceptions of the environment, tourism, and government. Correlation of all variables with income was considered as income often determines how influential they can be in the community or how likely they are to remain on the island. Ordinary Least Squares (OLS) testing was done using Microsoft Excel on a number of variables, including income, age, houses with latrines, opposition to joining the EU, among others. Due to Excel's limitation to 16 independent variables, regression analysis was performed 6 times, once for each individual survey section. Dummy variables were used for categorical independent variables, excluding the least common category in the question. For example, for the residency type question, vacation, dual, and permanent were independent variables with 1 for yes and 0 for no, and rental type was excluded. Results can be seen in the appendix. A complete OLS was performed in GIS as well to consider all variables together.

Geographically Weighted Regression was also used to take into account location of variables, using a fixed kernel type and an AICc bandwidth. The test was performed 6 times, once for each survey section, and traits considered correlated to income (by OLS) had their coefficient estimates tested for spatial pattern by Global Moran's I tests. Results can be seen in Fig. 2.

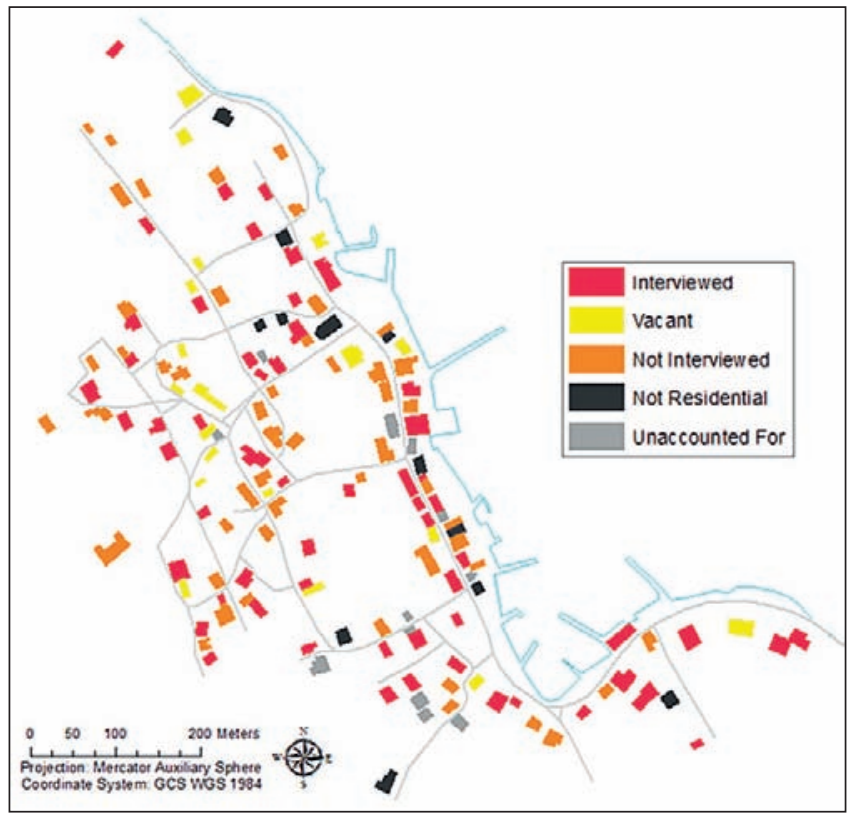

Fig. 2 Breakdown of building types

Sl. 2. Objekti prema sudjelovanju u istraživanju 


\section{RESULTS}

Of the 61 questions tested for hot spots using Global Getis-Ord General G tests, 4 were found to be significantly different from a spatial pattern by having strong clustering at a $90 \%$ confidence interval (Tab. 1). These included the monthly income of the heads of households, those who believe their sewage is affecting the groundwater, those who believe their sewage is affecting the sea, and those who have wells in their houses. Local Getis Ord $\mathrm{Gi}^{1}$ tests for the 4 traits were performed, and results are presented in Figs. 3, 4, 5 and 6.

Tab. 1 Global Getis-Ord General G Results: G values range between -1 and 1 positive implies clustering of high values

Tab. 1. Osnovni G-rezultati analize Global Getis-Ord: G-vrijednosti su između -1 $i+1$, pri čemu pozitivne vrijednosti označuju okupljanje viših vrijednosti

\begin{tabular}{|c|c|c|c|}
\hline Trait & Global G & Z-score & p value \\
\hline Income & 0.170654 & 2.753296 & 0.005900 \\
\hline Have a well & 0.123810 & 1.840733 & 0.065661 \\
\hline Think their sewage affects the groundwater & 0.112507 & 2.245529 & 0.024734 \\
\hline Think their sewage affects the sea & 0.113846 & 1.681010 & 0.092761 \\
\hline
\end{tabular}

Ordinary Least Squares results using income as the dependent variable can be seen in Tab. 2. Of the 6 survey section regressions, land use had the highest $r^{2}$ value at 0.339967 , meaning it had the best fit function, despite being low overall. Using a GIS, all variables were tested together as well, with income as the dependent variable, resulting in an $R^{2}$ of 0.10751, an F stat of 0.181944, and a Global Moran's I of Standard Residuals of - 0.02557 . The independent variables that were found to be significant at a $90 \%$ confidence level are shown in the appendix.

Geographically Weighted Regression was performed 6 times using income as the dependent variable. Traits found correlated to income (see Appendix) had their coefficient estimates tested for spatial pattern by Global Moran's I, and each test resulted in spatial clustering. Therefore it's unlikely the coefficients are reliable due to invalid homoscedasticity, implying that spatial weighting of trait regression is not applicable to this study. The focus should therefore just be placed upon OLS results.

\section{ANALYSIS}

While the Global G values are weak, hot and cold spots do exist and can aid in village planning. For example, cold spots in the Houses with Wells map (Fig. 3) show where additional water sources may be needed, and hot spots for effects on groundwater (Fig. 4) perhaps show where groundwater quality needs improvement. Income hot spots (Fig. 5) show the wealthy households set just off the main street, and a lack of cold spots implies there is no concentration of relatively poorer households. There is also a clear coastal vs. inland divide in perception of effect of sewage on the sea (Fig. 6), which perhaps implies coastal households believe the sea plays a larger part in sewage removal. 


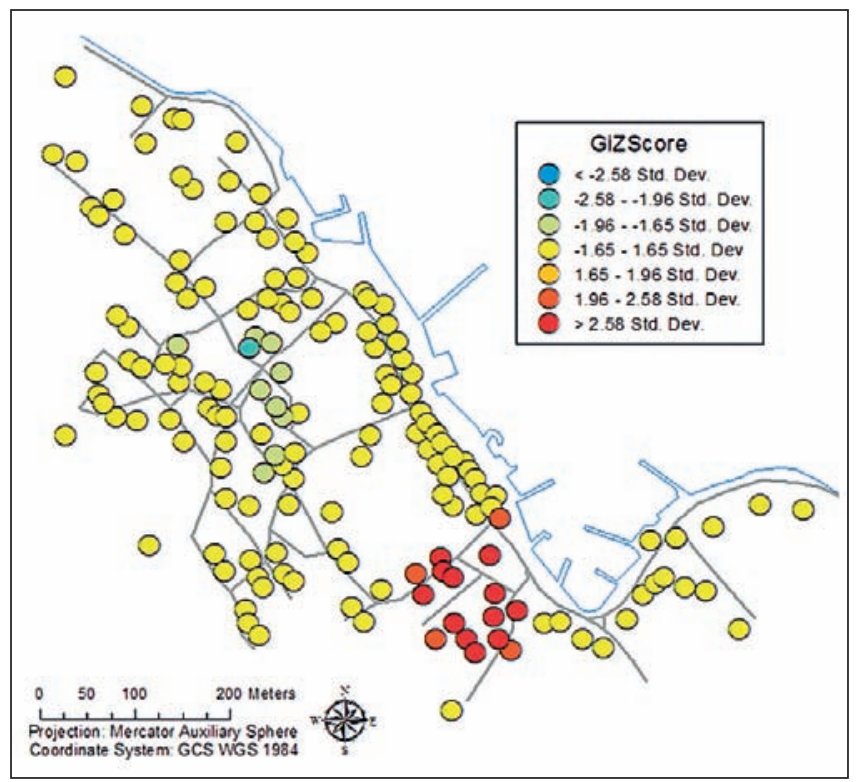

Fig. 3 Households with wells

Sl. 3. Domaćinstva s bunarima

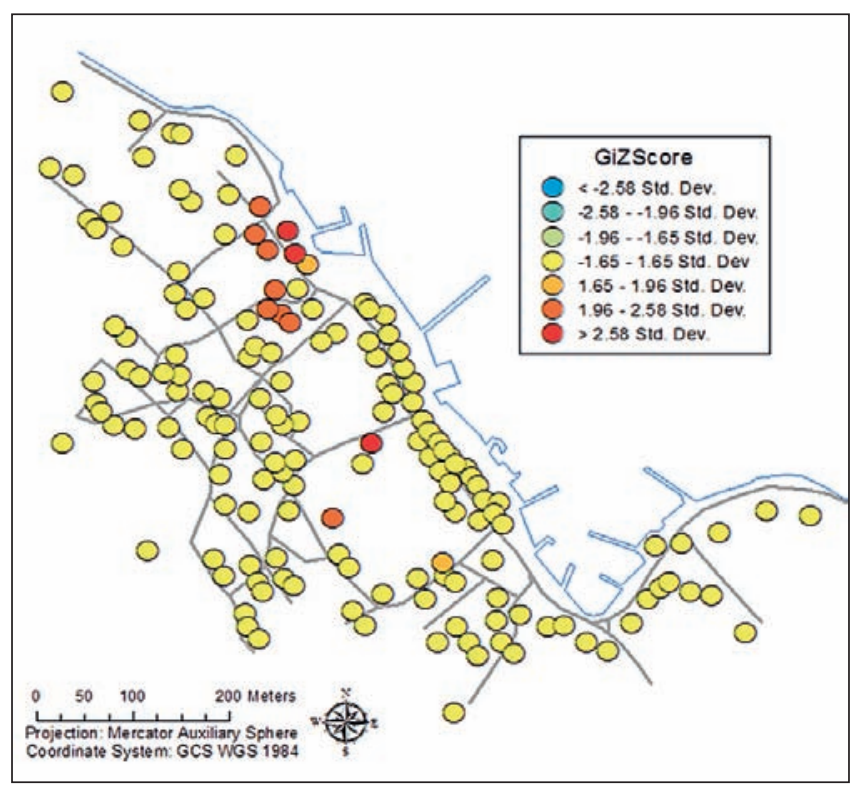

Fig. 4 Local Getis-Ord $\mathrm{G}^{1}$ results for household who believe their sewage affects the groundwater

Sl. 4. Lokalni rezultati Getis-Ord $G^{1}$ za kućanstva koja smatraju da njihove otpadne vode onečišćuju podzemne vode 


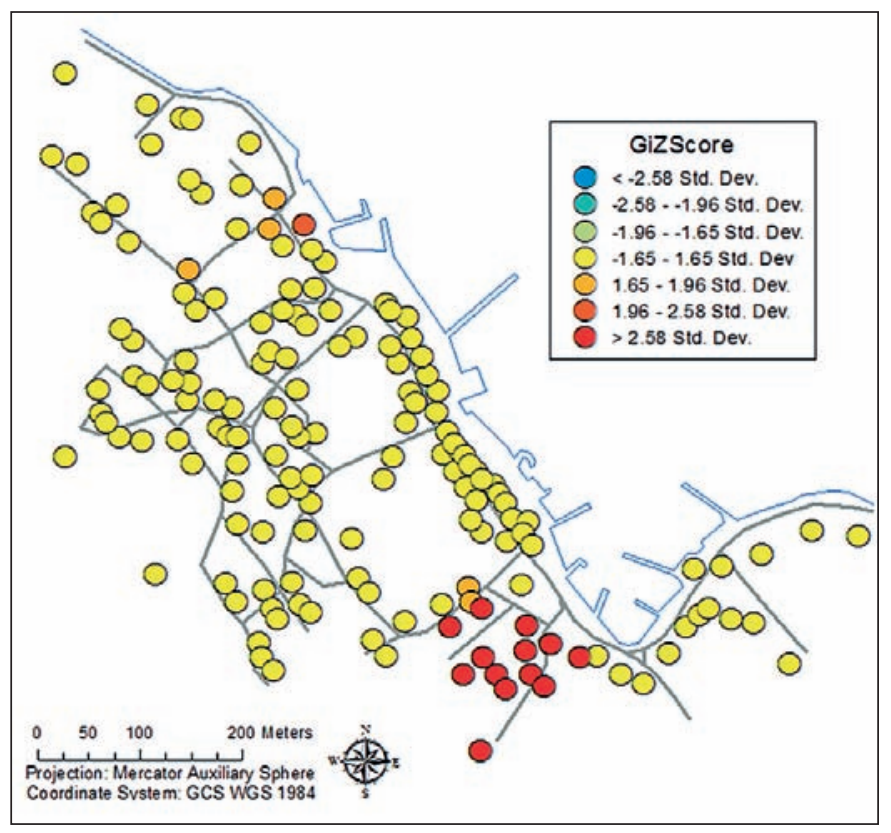

Fig. 5 Local Getis-Ord $\mathrm{G}^{1}$ results for income

Sl. 5. Lokalni rezultati Getis-Ord $G^{1}$ za prihod ispitanika

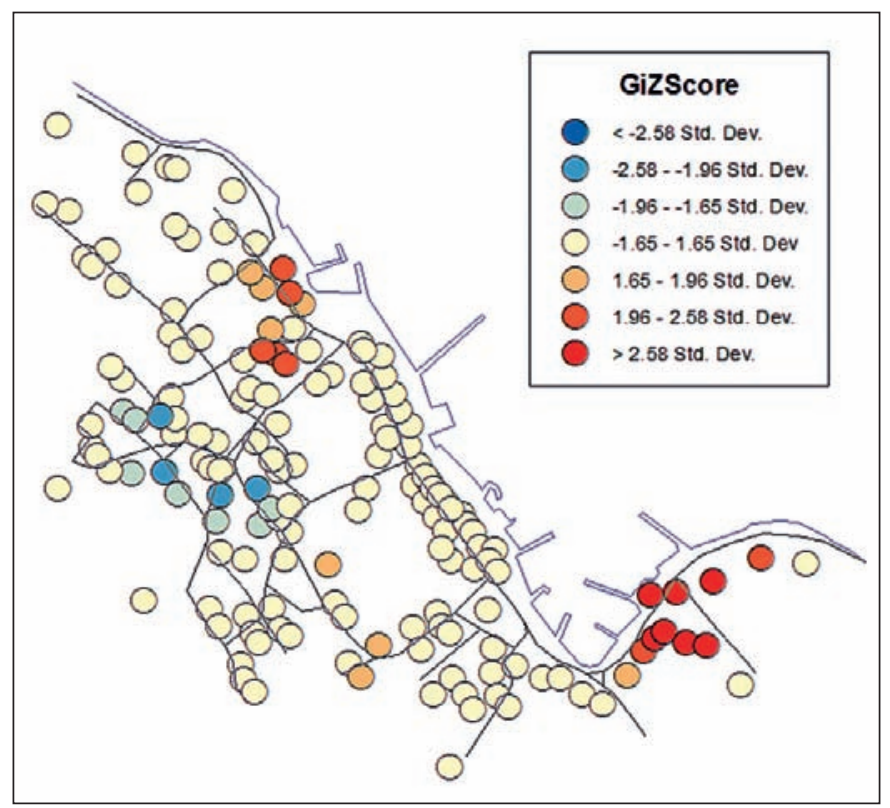

Fig. 6 Coastal vs. inland divide in perception of effect of sewage on the sea

Sl. 6. Razlika u percepciji onečišćenja mora kanalizacijom stanovništva uz obalu i u unutrašnjosti sela 
Low $r^{2}$ value implies a weakly fit line, and coefficients are much too high, though $t$ stats and $p$ values are strong. Perhaps a problem with projection is causing the bloated coefficient values. Taking into account only the sign of the coefficients can give some insight into the village, though.

Households that think that new house owners and joining the EU will change their way of life, but an increase in tourism will not, are somewhat wealthier. Thus, perhaps, further development of the island should focus on increasing the tourist market without increasing available housing to keep people satisfied. That would imply preserving present physical outlook of the village, and transforming available housing into tourist facilities.

Households that have latrines and do not think their sewage affects the groundwater are generally wealthier, so perhaps latrines will remain the dominant type of sewage system on the island due to their popularity and lack of environmental concern.

Households that have one source of income (usually a pension or a private business) are generally more wealthy, which shows how few opportunities there are outside of tourism.

\section{CONCLUSIONS}

When considering only the analysis already performed in this study, some conclusions can be drawn; however it is necessary to acknowledge that conclusions are likely to change once further testing has provided results.

This survey has shown how spatial analysis can provide insight into the current socio-economic situation of the village of Ilovik, and potential recommendations for future development. Recommendations from this analysis included locations for where new water sources should be created or where water quality should be addressed, where new septic systems are needed, and the general need for an increase in tourism and a decrease in available housing.

The next step towards a plan for future development would be to consider the current situation and recommendations in the context of the shift in economy associated with joining the EU. Only when these influences are considered can concrete, feasible plans be made that can appropriately address the sustainability of the island. 


\section{Appendix}

Tab. 2 OLS Results

Tab. 2. Rezultati OLS-a

\begin{tabular}{|l|c|c|c|}
\hline Dependent Variable: Income & Coefficient & t Stat & p value \\
\hline Independent Variable & 10991.31 & 1.98566 & 0.05318 \\
\hline Main Source of Income from Their Business & 9487.545 & 1.761137 & 0.085009 \\
\hline Main Source of Income from Their Pension & -2811.38 & -2.11055 & 0.040401 \\
\hline Number of Sources of Income & -1.15855 & -3.37833 & 0.001333 \\
\hline Amount Land Owned (meters squared) & 944.9483 & 5.258157 & $2.36 \mathrm{E}-06$ \\
\hline Number of Parcels of Land Owned & -1209.5 & -3.81414 & 0.000343 \\
\hline Number of Parcels of Land Unused & 5629.268 & 1.70983 & 0.093624 \\
\hline House Has a Latrine System & -9851.33 & -2.98179 & 0.004454 \\
\hline Think the Island's Sewage Affects the Groundwater & 6568.451 & 1.876425 & 0.066559 \\
\hline Think the Island's Sewage Affects the Sea & -8077.56 & -2.66726 & 0.01012 \\
\hline More Tourism Would Change Their Way of Life & 4328.164 & 1.893449 & 0.063763 \\
\hline New House Owners Would Change Their Way of Life & 3851.626 & 1.800916 & 0.077007 \\
\hline Joining the EU Would Change Their Way of Life & &
\end{tabular}

Tab. 3. Geographically Weighted Regression Results

Tab. 3. Rezultati regresije prema geografskom položaju

\begin{tabular}{|l|c|c|c|}
\hline Dependent Variable: Income & Moran's Index & z-score & p value \\
\hline Independent Variable & 0.52433 & 18.6227 & 0 \\
\hline Main Source of Income from Their Business & 0.66596 & 23.3925 & 0 \\
\hline Main Source of Income from Their Pension & 0.74628 & 26.1748 & 0 \\
\hline Number of Sources of Income & 0.55183 & 18.9421 & 0 \\
\hline Amount Land Owned (meters squared) & 0.51194 & 17.9294 & 0 \\
\hline Number of Parcels of Land Owned & 0.78352 & 27.1332 & 0 \\
\hline Number of Parcels of Land Unused & 0.61328 & 22.7447 & 0 \\
\hline House Has a Latrine System & 0.66762 & 23.9661 & 0 \\
\hline Think the Island's Sewage Affects the Groundwater & 0.49918 & 16.9154 & 0 \\
\hline Think the Island's Sewage Affects the Sea & 0.41782 & 14.8826 & 0 \\
\hline More Tourism Would Change Their Way of Life & 0.77501 & 27.0014 & 0 \\
\hline New House Owners Would Change Their Way of Life & 0.59613 & 19.4481 & 0 \\
\hline Joining the EU Would Change Their Way of Life & & \\
\hline
\end{tabular}

\section{NOTES}

1 http://resources.arcgis.com/en/help/main/10.1/index.html\#//005p00000010000000 


\title{
REFERENCES
}

Ciegis, R., Ramanauskiene, J., Martinkus, B., 2009: The Concept of Sustainable Development and its Use for Sustainability Scenarios, Inzinerine Ekonomika-Engineering Economics 2, 28-37.

Cross, M. D., 1996: Service Availability and Development among Ireland's Island Communities - the Implications for Population Stability, Irish Geography 29 (1), 13-26.

Deschenes, P. J., Chertow, M., 2004: An island approach to industrial ecology: towards sustainability in the island context, Journal of Environmental Planning and Management 47 (2), 201-217.

Hawkes, J., 2003: The Fourth Pillar of Sustainability: Culture's Essential Role in Public Planning, Cultural Development Network, Melbourne.

Krstinić Nižić, M., Ivanović, S., Drpić, D., 2010: Challenges to Sustainable Development in Island Tourism, SEE Journal 43-53.

Lajić, I., 2005: Novije demografsko stanje na otoku Iloviku, u: Analiza razvojnih potencijala otoka: Međunarodna radionica. Zbornik radova (ur. Črnjar, M., Šišić, S.), UNESCO Venice Office; Primorsko-goranska županija, Županijski zavod za održivi razvoj i prostorno planiranje; IUAV di Venezia, Rijeka, 58-63.

Lončar, J., Maradin, M., 2009: Environmental Challenges for Sustainable Development in the Croatian North Adriatic Littoral Region, Dela 31, 159-173.

Master plan Ilovik, 2011, http://www.sn.pgz.hr/default.asp?Link=odluke\&id=22741 (date of the downloading, January 2, 2012).

Pettit, C. J., 2005: Use of a Collaborative GIS-based Planning-support System to Assist in Formulating a Sustainable-development Scenario for Hervey Bay, Australia, Environment and Planning B: Planning and Design 32 (4), 523-45.

Stražičić, N., 1997: Cresko-Lošinjsko otočje - geografska obilježja, Geografski horizont 43 (2), $63-86$.

Yeh, A. G., Xia L., 2001: A Constrained CA Model for the Simulation and Planning of Sustainable Urban Forms by Using GIS, Environment and Planning B: Planning and Design 28 (5), 733-53.

SAŽETAK

\section{Prostorna analiza održivosti razvoja malih naselja: primjer naselja na otoku lloviku u Hrvatskoj}

\author{
Elena van Roggen, Mila Zlatić
}

U članku se iznose izvorni rezultati istraživanja provedenog u lipnju 2011. na malom otoku Iloviku, smještenom u sjevernom Jadranu, površine $4,6 \mathrm{~km}^{2}$, s osamdeset stalnih stanovnika i sto osamdeset kuća. Naselje je jedna od najmanjih otočnih zajednica u Hrvatskoj i nema adekvatno razvijenu prometnu povezanost s kopnom ni sustav vodoopskrbe i odvodnje. Ipak, u prijedlogu daljnjeg razvoja otoka nužno je uzeti u obzir percepciju lokalnog stanovništva, njihov socioekonomski status te specifične potrebe otoka.

Tijekom istraživanja intervjuirani su gotovo svi stanovnici koji su bili prisutni na otoku, odnosno 95\% stanovnika kućanstava sa stalnim stanovništvom te stanovništvo mnogih kućanstva koje povremeno boravi na otoku. Intervju za kućanstva sastojao se od pitanja o demografskim 
obilježjima, ekonomskom statusu, percepciji turizma i okoliša te vlastima. Osim toga putem modificiranog upitnika intervjuirani su svi vlasnici obrta i poslovnih subjekata, čime su prikupljeni podaci o socioekonomskim odnosima i upotpunjen je skup podataka o otočnom naselju. Aerofotogrametrijski snimci poslužili su kao podloga za digitalizaciju ulične mreže sa svim građevinama u naselju pomoću GIS-a. Svakom objektu pridruženi su podaci o ispitaniku te je provedena terenska provjera stanja gdje je to bilo potrebno.

Dva su osnovna cilja ove prostorne analize određivanje postojećeg stupnja održivosti naselja i preporuke za budući razvoj. Za procjenu trenutačnog stupnja održivosti naselja u prostornom kontekstu, upotrijebljene su metode prostorne statistike radi utvrđivanja odnosa između obilježja stanovnika i njihove lokacije na otoku. Varijable su testirane prostornom autokorelacijom radi definiranja obrazaca, „vrućih” i „hladnih” točaka te trendova kako bi se mogle predložiti potrebne promjene u infrastrukturi i razvoju. Uključivanjem rezultata intervjua geografski informacijski sustav ispunio je socioekonomsku prazninu u tradicionalnim metodama planiranja.

Ovaj primjer pokazuje kako prostorna analiza pruža uvid u trenutačnu socioekonomsku situaciju u naselju Iloviku i nudi preporuke za daljnji razvoj. Prijedlozi koji proizlaze iz analize uključuju lokacije na kojima su potrebni dodatni izvori vode, lokacije na kojima je nužno povećanje kvalitete vode, lokacije s potrebnim novim septičkim jamama te opću potrebu za razvojem turizma i smanjenjem broja praznih i napuštenih kuća. Ostali prijedlozi mogu proizaći iz pomna razmatranja situacije na otoku iznesene $u$ radu.

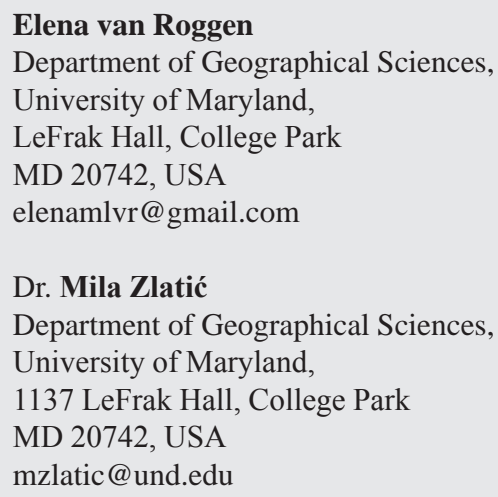

